\title{
PENGARUH TEKNIK PENILAIAN dan METODE BELAJAR TERHADAP PEMAHAMAN METAKOGNISI BIOLOGI \\ (Eksperimen pada SMA Negeri di Kota Bekasi)
}

\section{THE INFLUENCE OF ASSESSMENT TECHNIQUES and LEARNING METHODS ON THE UNDERSTANDING OF BIOLOGICAL METACOGNITION \\ (Experiments on State High Schools in Bekasi City)}

\author{
Ahmad Fauzan ${ }^{1 *}$ \\ ${ }^{1}$ Mahasiswa Fakultas Pascasarjana Pendidikan Matematika dan Ilmu Pengetahuan Alam \\ Universitas Indraprasta PGRI Jakarta, Indonesia \\ *Email: fauzan lina23@yahoo.com
}

Diterima: 15 Mei 2020. Disetujui: 02 Juni 2020. Dipublikasikan: 19 Agustus 2020

\begin{abstract}
Abstrak: Penelitian bertujuan menganalisis dan menguji kebenaran hipotesis pengaruh teknik penilaian dan metode belajar terhadap pemahaman metakognisi biologi. Hipotesis penelitian yang diuji: 1)Terdapat pengaruh metode pembelajaran terhadap kemampuan metakognisi biologi. 2)Terdapat pengaruh teknik penilaian terhadap kemampuan metakognisi biologi. 3)Terdapat pengaruh interaksi teknik penilaian dan metode pembelajaran terhadap kemampuan metakognisi biologi. Penelitian dilakukan dengan metode eksperimen. Populasi siswa kelas X SMA Negeri Kota Bekasi dengan sampel sebanyak 80 siswa, dengan teknik sampling simple random sampling. Instrumen penelitian yang digunakan tes soal essay sebanyak 10 butir yang telah diuji homogenitas dengan besar $\chi^{2}$ hitung $<\chi_{\text {tabel }}$ $(4,46<7,81)$. Analisis data menggunakan analysis of varians (ANOVA) dua arah. Hasil pengujian hipotesis diperoleh kesimpulan sebagai berikut: 1) Terdapat pengaruh metode pembelajaran terhadap kemampuan metakognisi biologi hal tersebut dibuktikan dengan Sig. 0,000<0,05 dan Fh 27,715. 2) Terdapat pengaruh teknik penilaian terhadap kemampuan metakognisi biologi hal tersebut dibuktikan dengan Sig. 0,000<0,05 dan Fh 17,478. 3) Terdapat pengaruh interaksi teknik penilaian dan metode pembelajaran terhadap kemampuan metakognisi biologi hal tersebut dibuktikan dengan Sig. 0,048<0,05 dan Fh 4,052. Hasil penelitian berguna untuk meningkatkan kualitas pembelajaran dan penilaian sehingga mampu untuk mengoptimalisasi pemahaman metakognisi biologi di tingkat SMA.
\end{abstract}

Kata kunci: metakognisi, protista, teknik penilaian, metode belajar.

Abstract: Research aims at analyzing and testing the truth hypothesis of the influence of assessment techniques and methods of learning towards the understanding of biological sciences. Research hypothesis tested: 1) There is an influence on the method of learning the ability of biology. 2) There is an influence of assessment techniques on the ability of biological sciences. 3) There is an influence on the interaction of assessment techniques and methods of learning of biological skills. Research is conducted by experimental methods. A student population of grade $\mathrm{X}$ SMA Negeri Bekasi with samples of 80 students, with simple random sampling technique. The research instrument used is a 10 grain essay test that has been tested homogenity with large $\chi^{2}$ count $<\chi$ table $(4.46<7.81)$. Analyze data using analysis of variance (ANOVA) in two directions. The results of the hypothesis testing were obtained the following conclusions: 1) There is an influence on the method of learning to the ability of biological methods of biology is evidenced by Sig. $0.000<0.05$ and Fh 27.715. 2) There is an influence of assessment techniques on the ability of biological engineering, it is evidenced by Sig. $0.000<0.05$ and Fh 17.478. 3) There is a influence of the interaction of assessment techniques and methods of learning to the ability of biological sciences is evidenced by the Sig. $0.048<0.05$ and Fh 4.052. Research results are useful to improve the quality of learning and assessment so that it is able to optimize the understanding of biological knowledge at high school level.

Keywords: metacognition, protista, assessment techniques, learning methods.

\section{PENDAHULUAN}

Keberhasilan hidup yang dimiliki seseorang tidak terlepas dari kemampuannya berinteraksi dengan alam dan lingkungannya serta menggunakan pengalaman yang dilalui untuk menyelesaikan masalah serupa yang dihadapi dikemudian hari. Keterampilan mempelajari kondisi alam dan lingkungan menjadi dasar utama bagi manusia untuk dapat melanjutkan kehidupan [1]. Melalui akal dan pikirannya manusia dapat memanfaatkan berbagai kondisi alam dan lingkungan demi kebutuhan hidup. Kegiatan tersebut merupakan salah satu bentuk belajar yang paling hakiki. Biologi merupakan salah satu bidang studi yang secara intensif membahas dan mempelajari tentang alam dan lingkungan serta mahkluk hidup yang ada di dalamnya. Pengetahuan tentang biologi telah memberi banyak keuntungan bagi manusia, karena dengan pembelajaran tersebut 
telah mampu membuka cakrawala tentang rahasia mahkluk hidup [2]. Materi pelajaran biologi secara bertahap telah disampaikan sejak dari usia sekolah dasar, hal ini dilakukan untuk memberi pengetahuan awal bagi siswa tentang kehidupan dan mahkluk hidup. Biologi mempelajari tentang struktur fisik dan fungsi alat-alat tubuh manusia serta mempelajari sekitar lingkungan. Serta memiliki kekhasan dalam mengembangkan berfikir logis melalui klasifikasi. Seorang guru biologi perlu memotivasi siswanya agar senang belajar biologi, memberi penguatan dan memperlihatkan bahwa belajar biologi yang baik bukan dengan cara menghafal [3]. Berikut merupakan ciri-ciri sains antara lain [4]:

a. Obyek kajian berupa benda konkret dan dapat ditangkap indera.

b. Dikembangkan berdasarkan pengalaman empiris (pengalaman nyata).

c. Memiliki langkah-langkah sistematis yang bersifat baku.

d. Menggunakan cara berfikir logis, yang bersifat deduktif artinya berfikir dengan menarik kesimpulan dari hal-hal yang umum menjadi ketentuan khusus.

e. Hasil berupa hukum-hukum yang berlaku umum, dimanapun diberlakukan.

Biologi juga merupakan cabang sains yang mempelajari berbagai permasalahan makhluk hidup. Dalam mempelajari sains terdiri dari 3 komponen yaitu: [5]

1) Sikap Ilmiah Merupakan sikap yang harus dimiliki untuk berlaku obyektif dan jujur saat mengumpulkan dan menganalisa data.

2) Proses Ilmiah Merupakan perangkat ketrampilan kompleks yang digunakan dalam melakukan kerja ilmiah. Didalamnya terdapat Keterampilan proses yang terdiri dari:

a) Mengobservasi: Mencari gambaran atau informasi tentang objek penelitian melalui indera.

b) Menggolongkan: Untuk mempermudah dalam mengidentifikasi suatu permasalahan.

c) Menafsirkan: Memberikan arti sesuatu fenomena/kejadian berdasarkan atas kejadian lainnya.

d) Mempraktikkan: Memperkirakan kejadian berdasarkan kejadian sebelumnya serta hukum-hukum yang berlaku.

3) Produk ilmiah dengan menggunakan sikap dan proses ilmiah, para ahli memperoleh penemuanpenemuan yang dapar berupa fakta atau teori. Produk ilmiah sangat berpengaruh pada perkembangan ilmu dan teknologi.

Proses pembelajaran di Indonesia masih menekankan pada transfer pengetahuan tetapi kurang mengembangkan kemampuan bernalar siswa. Pengetahuan yang diberikan secara langsung kepada siswa hanya dapat meningkatkan kemampuan mengingat saja tetapi kurang meningkatkan kemampuan bernalar. Sedangkan tujuan pendidikan adalah mengembangkan pemikir-pemikir yang matang yang dapat menggunakan pengetahuan yang dimilikinya dalam kehidupan nyata. Banyak upaya telah dilakukan mulai dari penerapan kurikulum hingga penerapan stategi dan metode pembelajaran serta peningkatan kualitas guru melalui pelatihanpelatihan. Namun upaya tersebut belum menunjukkan hasil yang signifikan [6].

Banyak inovasi dan metode pembelajaran yang dilakukan guru di kelas kurang berhasil karena dalam implementasinya kurang memperhatikan karakteristik siswa, termasuk perkembangan kemampuan berpikirnya [7], serta masih banyak ditemukan bahwa banyak siswa berdaya imajinasi yang lemah dan materi pembelajaran IPA selalu disajikan dalam bentuk yang abstrak [8]. Hasil analisis kemampuan berpikir tahun 2001 dan tahun 2003 pada mahasiswa ilmu keolahragaan Unesa ditemukan bahwa lebih dari $90 \%$ mahasiswa yang diterima hanya mampu menggunakan kemampuan berpikir konkrit [9].

Melihat kenyataan diatas penulis dapat menjelaskan bahwa penguasaan siswa terhadap materi bidang studi biologi belumlah optimal dan juga tidak merata, beberapa siswa mampu meraih hasil belajar yang baik namun sebagian siswa lainnya hanya mampu meraih prestasi sesuai KKM bahkan beberapa siswa harus mengikuti remedial karena hasil belajar yang dicapai masih jauh di bawah KKM. Sejalan dengan berlangsungnya KBM, guru jarang sekali untuk mencoba metode belajar baru yang mampu memacu kemampuan dasar dan pengetahuannya mengenai biologi, mereview dan memberikan latihan soal essay dan multiple choice terkait dengan materi yang sudah berlalu, hal ini terjadi karena guru beranggapan siswa mampu untuk mengingat materi yang telah diajarkan tanpa direview kembali.

Kondisi ini terjadi pada sebagian besar siswa SMA yang merasa kesulitan memahami materi pelajaran biologi, hal ini dapat dilihat dari hasil belajar siswa yang rata-rata dibawah KKM. Siswa banyak mengalami kesulitan dalam memahami soal serta menginterpretasikan jawaban, meskipun pada awalnya siswa dapat mengerjakan soal dengan baik, tetapi selang beberapa waktu kedepan siswa tersebut lupa atau sama sekali tidak mampu untuk menjawab soal pada saat evaluasi akhir dengan materi yang sudah pernah diajarkan.

Era pendidikan saat ini yang dipengaruhi oleh revolusi industri 4.0 banyak berbagai macam jenis tes dan metode pembelajaran yang digunakan untuk memacu proses kognisi siswa. Sebagai seorang guru hendaknya mampu memilih metode pembelajaran dan jenis tes yang tepat dan efektif dengan kondisi siswa dan sekolah dimana guru tersebut mengajar [10]. Pemilihan teknik penilain dan metode belajar yang salah akan menyebabkan nilai hasil belajar siswa akan mengalami penurunan dan tidak dapat untuk mencapai nilai KKM (Kriteria Ketuntasan Minimal) yang grade nilainya disusun oleh masing-masing sekolah. Jika nilai tes kurang 
dari nilai KKM, maka siswa tersebut dianggap tidak mampu menguasai materi yang diajarkan sehingga berakibat pada penurunan hasil belajarnya, lebih bahaya lagi apabila siswa banyak yang tidak menguasai mata pelajaran biologi maka dipastikan siswa tersebut tidak akan mampu memilih jurusan dengan pengembangan dasar biologi seperti teknik pertanian, teknologi pangan dan lain sebagainya sehingga akses pemilihan jurusan akan terlalu sempit dikarenakan siswa tersebut tidak mengetahui dasar biologi.

Sejak awal memasuki dunia pendidikan formal, peserta didik sudah mulai dikenalkan dengan bermacam bentuk tes seperti: menyusun angka, menulis bentuk huruf dan angka, serta menyusun gambar objek dari pola acak, serta metode dasar pembelajaran, seperti: metode diskusi, metode ceramah, serta metode penemuan atau discovery.. Metode tersebut dilakukan oleh seorang guru agar peserta didik terbiasa untuk melatih kemampuan kognitif yang nantinya akan menunjang pembelajaran di level yang lebih tinggi. Banyak diantara para guru yang hanya menjelaskan dan menulis materi secara panjang lebar sehingga siswa merasa kantuk dan dapat tertidur dikelas, sehingga guru akan menegur siswa tersebut dengan anggapan siswa tersebut tidak menghormati guru yang sedang mengajar, tetapi memang kenyataan guru memberikan pola pengajaran dan metode yang membosankan [11].

Penulis sadar akan dampak tersebut, dimana sering kali orang tua siswa mengeluh terhadap penurunan nilai setiap kali pembagian rapor dilaksanakan, baik rapor PAS (Penilaian Akhir Semester) satu maupun dua. Dengan melihat kenyataan tersebut, penulis ingin memberikan solusi dengan cara pemberian metode belajar baru dan jenis tes yang tepat sehingga memberikan dampak yang positif untuk perkembangan metakognisi siswa.

Pemberian teknik penilaian serta metode pembelajaran yang tepat dan secara konsisten diterapkan oleh guru memberikan keuntungan bagi peserta didik, karena peserta didik dipacu untuk mengembangkan ide-ide terkait tentang permasalahan yang diujikan dalam paket ujian, sehingga akan memacu kemampuan metakognisi peserta didik untuk mengkonstruk dan mengingat kembali akan materi yang pernah disampaikan [12].

\section{METODE PENELITIAN}

Penelitian ini menggunakan metode penelitian kuantitatif. Hal ini dikarenakan dalam pengambilan, pengumpulan, dan sampai memperoleh hasil datanya diperoleh dalam bentuk skor atau angka. Dalam penelitian eksperimen perlu adanya kontrol langsung pada variabel bebasnya [13]. Metode yang digunakan dalam penelitian ini adalah metode penelitian quasi eksperimen. Adapun desain eksperimennya dapat djelaskan pada Tabel 1.
Tabel 1. Desain Penelitian Eksperiment Treatment by Treatment $2 \times 2$

\begin{tabular}{lcc}
\hline \multirow{2}{*}{ Metode belajar (B) } & \multicolumn{2}{c}{ Teknik penilaian (A) } \\
\cline { 2 - 3 } & $\begin{array}{c}\text { Essay } \\
\text { (A1) }\end{array}$ & Multiple choice (A2) \\
Discovery (B1) & $\mathrm{Y}_{\mathrm{B} 1 \mathrm{~A} 1}$ & $\mathrm{Y}_{\mathrm{B} 1 \mathrm{~A} 2}$ \\
Konvensional (B2) & $\mathrm{Y}_{\mathrm{B} 2 \mathrm{~A} 1}$ & $\mathrm{Y}_{\mathrm{B} 2 \mathrm{~A} 2}$ \\
\hline
\end{tabular}

\section{Keterangan:}

1. Variabel bebas (A) : Teknik Penilaian

a) $\mathrm{A}_{1}$ : Siswa yang diberi teknik penilaian essay

b) $A_{2}$ : Siswa yang diberi teknik penilaian multiple choice

2. Variabel bebas (B) : Metode Belajar

a) $\mathrm{B}_{1}$ : Siswa yang diberi metode belajar discovery

b) $\mathrm{B}_{2}$ : Siswa yang diberi metode belajar konvensional

3. $\mathrm{B}_{1} \mathrm{~A}_{1}$ : Pemahaman Metakognisi siswa yang diberikan metode pembelajaran discovery dengan teknik penilaian essay

4. $\mathrm{B}_{1} \mathrm{~A}_{2}$ : Pemahaman Metakognisi siswa yang diberikan metode pembelajaran discovery dengan metode pembelajaran multiple choice

5. $\mathrm{B}_{2} \mathrm{~A}_{1}$ : Pemahaman Metakognisi siswa yang diberikan metode pembelajaran konvensional dengan teknik penilaian essay

6. $\mathrm{B}_{2} \mathrm{~A}_{2}$ : Pemahaman Metakognisi siswa yang diberikan metode pembelajaran konvensional dengan teknik penilaian multiple choice

\section{Langkah - langkah Penelitian}

Perlakuan terhadap subjek dalam penelitian ini berupa pemberian teknik penilaian dan metode pembelajaran. Teknik penilaian yang dimaksud adalah essay dan multiple choice dan metode pembelajaran yang dimaksud adalah discovery dan konvensional (ceramah) yang dilaksanakan di SMA Negeri 3 dan SMA Negeri 8 Kota Bekasi. Skor untuk mengetahui pemahaman metakognisi biologi diukur menggunakan tipe soal bertipe essay yang telah diuji coba diluar kelas sampel dan divalidasi sebelumnya. Setelah selesai pengerjaan, soal evaluasi akhir dan lembar jawaban peneliti ambil kemudian dianalisis dengan penskoringan menggunakan skala rubrik.

Populasi penelitian adalah seluruh siswa di SMA Negeri 3 dan SMA Negeri 8 Bekasi dengan jumlah total 180 siswa di SMA Negeri 3 dan 210 siswa di SMA Negeri 8 Kota Bekasi. Untuk pengambilan sampel penelitian ini, siswa-siswi yang tergabung dalam populasi terjangkau diambil empat kelas untuk diberikan perlakuan yaitu kelas $\mathrm{X}-1, \mathrm{X}-2$, $\mathrm{X}-3, \mathrm{X}-4$ dengan jumlah 30 siswa. Pemilihan sampel dilakukan dengan teknik simple random sampling dengan tahapan pengambilan secara acak empat kelas dan masing-masing kelas dipilih lagi secara acak sebagai subjek penelitian 20 siswa. 


\section{Subjek Penelitian}

Populasi terjangkau dalam penelitian ini adalah siswa peserta mata pelajaran biologi semester 2 kelas X bab protista Tahun Pelajaran 2018/2019.

\section{Instrumen Penelitian}

\section{a. Definisi Konseptual}

Metakognisi biologi peserta didik adalah tingkat pencapaian kemampuan pengetahuan peserta didik tentang pemahaman materi biologi yang meliputi materi protista, serta pencapaian hasil belajar, keaktifan, sikap yang terkait dengan wawasan mereka tentang biologi.

\section{b. Definisi Operasional}

Metakognisi biologi yang diperoleh melalui nilai tes. Untuk melihat seberapa jauh siswa menguasai materi maka, peneliti memberikan tes evaluasi yang nantinya dianalisis dalam bentuk skor yang diperoleh dari siswa. Tes yang diberikan kepada siswa berjumlah 10 butir dengan tipe essay.

\section{Teknik Analisis Data}

Hasil penelitian yang telah dilakukan maka akan diperoleh data kuantitatif. Data kuantitatif didapat melalui tes kemampuan metakognisi biologi dengan skala rubrik. Setelah data diperoleh, kemudian dianalisis untuk didiskripsikan dan diberikan tafsiran. Pengelolaan data kuantitatif dilakukan melalui dua tahapan utama.

1. Tahap pertama: menguji persyaratan statistik yang diperlukan sebagai dasar dalam pengujian hipotesis, yaitu uji normalitas dan uji homogenitas varians.

2. Tahap kedua: menguji ada atau tidak adanya perbedaan dari masing-masing kelompok dengan menggunakan uji bartlett, uji ANAVA dua jalur dengan bantuan SPSS 20.0.

\section{HASIL DAN PEMBAHASAN}

Penelitian ini menggunakan metode analisa data ANAVA $2 \times 2$ dengan model treatment by treatment. Treatment yang dilakukan adalah metode pembelajaran discovery yang dilaksanakan pada kelas eksperimen dan pembelajaran melalui metode konvensional (ceramah) yang dilaksanakan pada kelas kontrol. Dari treatment metode pembelajaran tersebut lalu akan di treatment kembali menggunakan teknik penilaian essay sebagai kelas eksperimen dan multiple choice sebagai kelas kontrol. Dari perlakuan atau treatment berkala tersebut maka untuk data skor metakognisi biologi siswa diambil dengan menggunakan tes akhir bertipe essay berjumlah 10 butir soal yang telah divalidasi dan dipergunakan untuk menentukan pengukuran tingkat pemahaman metakognisi biologi.

Penelitian relevan sebelumnya telah memberikan data dan hasil yang mendukung penelitian ini dikembangkan kembali seperti penelitian yang berjudul penggunaan tes essay dalam evaluasi pembelajaran. Hasil penelitian tersebut memberikan hasil bahwa siswa akan belajar lebih serius dan teliti untuk ujian bentuk tes essay daripada tes objektif [14]. Serta penelitian yang relevan sebelumnya yang berjudul pengaruh model pembelajaran discovery learning terhadap keterampilan berpikir kreatif siswa pada materi sifatsifat cahaya. Penelitian tersebut memberikan data uji hipotesis dengan menggunakan uji Wilcoxon diperoleh sig. 1-tailed sebesar $0,000 \leq 0,05$ yang artinya menunjukkan $\mathrm{H}_{0}$ ditolak, artinya pembelajaran menggunakan model discovery learning dapat meningkatkan keterampilan berpikir kreatif siswa [15].

Untuk mengetahui perbedaan pemahaman metakognisi biologi terlebih dahulu dilakukan uji normalitas dan homogenitas varians data, dan didapat kesimpulan[16].

\begin{tabular}{|c|c|c|c|c|c|}
\hline \multicolumn{6}{|c|}{ One-Sample Kolmogorov-Smirnov Test } \\
\hline & & B1_A1 & B1_A2 & B2_A1 & B2_A2 \\
\hline $\mathrm{N}$ & & 20 & 20 & 20 & 20 \\
\hline \multirow[t]{2}{*}{ Normal Parameters ${ }^{a, b}$} & Mean & 84,7500 & 74,7500 & 73,0000 & 69,5000 \\
\hline & Std. Deviation & 7,69056 & 6,78136 & 7,50438 & 6,86333 \\
\hline \multirow[t]{3}{*}{ Most Extreme Differences } & Absolute & ,182 &, 285 & 155 & 179 \\
\hline & Positive &, 182 &, 285 & 107 & 171 \\
\hline & Negative &,- 109 &,- 165 &,- 155 &,- 179 \\
\hline Kolmogorov-Smirnov Z & &, 812 & 1,276 &, 694 &, 801 \\
\hline Asymp. Sig. (2-tailed) & &, 525 &, 077 &, 722 &, 543 \\
\hline \multicolumn{6}{|c|}{ a. Test distribution is Normal. } \\
\hline
\end{tabular}

Gambar 1. Uji Normalitas

Gambar 1 di atas terlihat bahwa nilai pada kolom Sig pada metode Kolmogorov-Smirnov untuk semua sampel lebih besar dari 0,05. (B1-A1 Sig. = $0.525>0,05$, B1-A2 Sig. $=0.077>0,05$, B2-A1 $=$ $\mathbf{0 , 7 2 2}>\mathbf{0 , 0 5}$ dan B2-A2 $=\mathbf{0 , 5 4 3}>\mathbf{0 , 0 5}$ ) sehingga $\mathrm{H}_{0}$ diterima, dengan kata lain bahwa data dari semua sampel pada tiap kelompok data tersebut berdistribusi normal. Pengujian normalitas

menggunakan uji Bartlett adapun hipotesis yang diuji adalah:

(a). Tolak $\mathrm{H}_{0}$ jika $\chi^{2}$ hitung $>\chi_{(1-\alpha)(\mathrm{k}-1) \text { atau }}$ 
(b). Terima $\mathrm{H}_{0}$ jika $\chi^{2}$ hitung $<\chi_{(1-a)}(\mathrm{k}-1)$ atau $\chi^{2}$ hitung $<\chi_{\text {tabel }}$

Hasil perhitungan menghasilkan $\chi^{2}{ }_{\text {hitung }}<$

$\chi_{\text {tabel }}(\mathbf{4 , 4 6}<\mathbf{7 , 8 1})$, maka $\mathrm{H}_{0}$ diterima, dan dismpulkan keempat kelompok data mempunyai varian yang sama atau homogen. Distribusi pemahaman metakognisi biologi berdasarkan teknik penilaian dan metode pembelajaran dijelaskan pada Tabel 2, 3, 4, dan 5 .

Tabel 2. Deskripsi statistik data pemahaman metakognisi biologi kelompok yang diajar dengan metode discovery (B1)

\begin{tabular}{ccccccc}
\hline & $\mathrm{N}$ & Minimum & Maximum & Mean & Median & $\begin{array}{c}\text { Std. } \\
\text { Deviation }\end{array}$ \\
\cline { 2 - 6 } B1 & 40 & 65,00 & 100,00 & 79,75 & 77,50 & 8,76 \\
Valid N (listwise) & 40 & & & & & \\
\hline
\end{tabular}

Tabel 3. Deskripsi statistik data pemahaman metakognisi biologi kelompok yang diajar dengan metode konvensional (B2)

\begin{tabular}{ccccccc}
\hline & $\mathrm{N}$ & Minimum & Maximum & Mean & Median & $\begin{array}{c}\text { Std. } \\
\text { Deviation }\end{array}$ \\
\cline { 2 - 6 } B2 & 40 & 55,00 & 85,00 & 71,25 & 70,00 & 7,31 \\
Valid N (listwise) & 40 & & & & & \\
\hline
\end{tabular}

Tabel 4. Deskripsi statistik data pemahaman metakognisi biologi kelompok yang dinilai dengan teknik penilaian multiple choice (A2)

\begin{tabular}{ccccccc}
\hline & $\mathrm{N}$ & Minimum & Maximum & Mean & Median & $\begin{array}{c}\text { Std. } \\
\text { Deviation }\end{array}$ \\
\cline { 2 - 6 } A2 & 40 & 55,00 & 95,00 & 72,12 & 70,00 & 7,24 \\
Valid N (listwise) & 40 & & & & & \\
\hline
\end{tabular}

Tabel 5. Deskripsi statistik data pemahaman metakognisi biologi kelompok yang dinilai dengan teknik penilaian essay (A1)

\begin{tabular}{ccccccc}
\hline & $\mathrm{N}$ & Minimum & Maximum & Mean & Median & $\begin{array}{c}\text { Std. } \\
\text { Deviation }\end{array}$ \\
\cline { 2 - 6 } A1 & 40 & 60,00 & 100,00 & 78,87 & 80,00 & 9,93 \\
Valid N (listwise) & 40 & & & & & \\
\hline
\end{tabular}

Perbedaan pemahaman metakognisi biologi siswa yang di nilai dengan teknik penilaian essay dan multiple choice serta diajar dengan metode pembelajaran konvensional dan discovery maka dilakukan uji ANAVA dua jalur. Kriteria pengujian adalah jika nilai sig. lebih kecil dari $\alpha=0,05$, maka hipotesis nol ditolak [17]. Hasil perhitungan uji ANAVA dua jalur dapat dijelaskan pada Tabel 6 .

Tabel 6. Uji Hipotesis Penelitian

\begin{tabular}{|c|c|c|c|c|c|}
\hline \multicolumn{6}{|c|}{ Tests of Between-Subjects Effects } \\
\hline \multicolumn{6}{|c|}{ Dependent Variable : Pemahaman_Metakognisi_Biologi } \\
\hline Source & $\begin{array}{c}\text { Type III Sum of } \\
\text { Squares }\end{array}$ & df & Mean Square & $\mathbf{F}$ & Sig. \\
\hline Corrected Model & $2567,500^{\mathrm{a}}$ & 3 & 855,833 & 16.415 & .000 \\
\hline Intercept & 456020,000 & 1 & 456020,000 & 8746,377 & .000 \\
\hline Teknik_Penilaian & 911,250 & 1 & 911,250 & 17,478 & .000 \\
\hline Metode_Belajar & 1445,000 & 1 & 1445,000 & 27,715 & .000 \\
\hline $\begin{array}{l}\text { Teknik_Penilaian } \\
\text { * Metode_Belajar }\end{array}$ & 211,250 & 1 & 211,250 & 4.052 & .048 \\
\hline Error & 3962.500 & 76 & 52,138 & & \\
\hline Total & 462550.000 & 80 & & & \\
\hline $\begin{array}{l}\text { Corrected Total } \\
\text { Corrected Model }\end{array}$ & 6530,000 & 79 & & & \\
\hline
\end{tabular}


1. Pengaruh metode pembelajaran terhadap pemahaman metakognisi biologi. (main effect).

Berdasarkan ketentuan di atas maka untuk pengujian hipotesis ini adalah dengan memperhatikan nilai Sig pada tabel Tests of Between-Subjects Effects untuk baris Metode Pembelajaran dengan ketentuan jika kurang dari 0,05 maka hasil pengujian tersebut signifikan atau $\mathrm{H}_{0}$ ditolak. Pada Tabel 6 terlihat bahwa nilai Sig untuk baris motivasi belajar adalah 0,000, kurang dari $0,05($ Sig. $=\mathbf{0 , 0 0 0}<\mathbf{0 , 0 5})$ maka $\mathrm{H}_{0}$ ditolak sehingga $\mathrm{H}_{1}$ diterima. Dengan kata lain terdapat perbedaan pemahaman metakognisi biologi yang signifikan antara siswa yang diajar dengan metode pembelajaran discovery dengan yang diajar dengan menggunakan metode pembelajaran konvensional, atau dapat disimpulkan bahwa terdapat pengaruh metode pembelajaran yang telah diajarkan terhadap pemahaman metakognisi biologi yang diperolehnya.

2. Pengaruh teknik penilaian terhadap pemahaman metakognisi biologi (main effect).

Berdasarkan ketentuan di atas maka untuk pengujian hitopesis ini adalah berdasarkan nilai Sig pada tabel Tests of Between-Subjects Effects untuk baris Teknik_Penilaian dengan ketentuan jika kurang dari $\overline{0}, 05$ maka hasil pengujian tersebut signifikan atau $\mathrm{H}_{0}$ ditolak. Pada Tabel 6 terlihat terlihat bahwa nilai Sig untuk baris Teknik_Penilaian adalah 0,000, kurang dari 0,05 (Sig. $=\mathbf{0 , 0 0 0}<\mathbf{0 , 0 5})$ maka $\mathrm{H}_{0}$ ditolak sehingga $\mathrm{H}_{1}$ diterima. Dengan kata lain terdapat perbedaan pemahaman metakognisi biologi yang signifikan antara siswa yang dinilai dengan teknik penilaian essay dengan siswa yang dinilai dengan teknik penilaian multiple choice, atau dapat disimpulkan bahwa terdapat pengaruh teknik penilaian terhadap pemahaman metakognisi biologi siswa.

3. Pengaruh interaksi teknik penilaian dan metode belajar terhadap pemahaman metakognisi biologi siswa (interaction effect).

Berdasarkan ketentuan di atas maka untuk pengujian hitopesis ini adalah dengan memperhatikan nilai Sig pada tabel Tests of Between-Subjects Effects untuk baris Teknik_Penilaian*Metode_Belajar dengan ketentuan jika kurang dari 0,05 maka hasil pengujian tersebut signifikan atau $\mathrm{H}_{0}$ ditolak. Pada Tabel 6 terlihat. Terlihat bahwa nilai Sig untuk baris Teknik_Penilaian*Metode_Belajar adalah 0,048 , kurang dari 0,05 (Sig. $=\mathbf{0 , 0 4 8}<$ 0,05) maka $\mathrm{H}_{0}$ ditolak sehingga $\mathrm{H}_{1}$ diterima. Dengan kata lain terdapat pengaruh interaksi yang signifikan antara teknik penilaian dan metode pembelajaran terhadap pemahaman metakognisi biologi siswa.
Pengujian hipotesis dalam penelitian ini terdapat interaksi, maka dilakukan uji lanjut dengan menggunakan uji tukey yaitu:

1. Hipotesis perbedaan pemahaman metakognisi antara teknik penilaian essay (A1) dengan teknik penilaian multiple choice (A2) khusus kelompok yang di diajar dengan metode discovery (B1).

Hasil pengujian Q hitung > Q tabel (6,19> 3,96) maka, $\mathrm{H}_{0}$ ditolak dan disimpulkan Ada perbedaan pemahaman metakognisi biologi yang signifikan antara yang menggunakan teknik penilaian essay (A1) dan dengan teknik penilaian multiple choice (A2) pada siswa yang menggunakan metode pembelajaran discovery (B1).

2. Hipotesis perbedaan pemahaman metakognisi antara teknik penilaian essay (A1) dengan teknik penilaian multiple choice (A2) khusus kelompok yang di diajar dengan metode konvensional (B2).

Hasil pengujian Q hitung $<$ Q tabel $(2,17<$ 3,96) maka, $\mathrm{H}_{0}$ diterima dan disimpulkan Tidak ada perbedaan pemahaman metakognisi biologi yang signifikan antara yang menggunakan teknik penilaian essay (A1) dengan teknik penilaian multiple choice (A2) pada siswa yang menggunakan metode pembelajaran konvensional (B2).

3. Hipotesis perbedaan pemahaman metakognisi antara metode pembelajaran discovery (B1) dengan metode pembelajaran konvensional (B2) khusus kelompok yang di nilai dengan teknik penilaian essay (A1).

Hasil pengujian Q hitung $>$ Q tabel (7,28 > 3,96) maka, ditolak dan disimpulkan Ada perbedaan pemahaman metakognisi biologi yang signifikan antara metode pembelajaran discovery (B1) dengan metode pembelajaran konvensional (B2) khusus kelompok yang di nilai dengan teknik penilaian essay (A1).

4. Hipotesis perbedaan pemahaman metakognisi antara metode pembelajaran discovery (B1) dengan metode pembelajaran konvensional (B2) khusus kelompok yang di nilai dengan teknik penilaian multiple choice (A2).

Kesimpulan karena Q hitung $<$ Q tabel $(3,25<3,96)$ maka, diterima dan disimpulkan Tidak ada perbedaan pemahaman metakognisi biologi yang signifikan antara metode pembelajaran discovery (B1) dengan metode pembelajaran konvensional (B2) khusus kelompok yang di nilai dengan teknik penilaian multiple choice (A2).

\section{KESIMPULAN}

Berdasarkan hasil analisa data, maka dapat disimpulkan bahwa:

Terdapat pengaruh yang signifikan metode pembelajaran, teknik penilaian terhadap kemampuan metakognisi biologi, serta pengaruh interaksi antara 
keduanya yaitu teknik penilaian dan metode belajar. Pengujian lebih lanjut dikarenakan adanya pengaruh interaksi yaitu: Adanya perbedaan pemahaman metakognisi biologi yang signifikan antara penggunaan teknik penilaian essay dan teknik penilaian multiple choice pada siswa yang menggunakan metode pembelajaran discovery. Tidak adanya perbedaan pemahaman metakognisi biologi yang signifikan antara penggunaan teknik penilaian essay dengan teknik penilaian multiple choice pada siswa yang menggunakan metode pembelajaran konvensional. Adanya perbedaan pemahaman metakognisi biologi yang signifikan antara metode pembelajaran discovery dengan metode pembelajaran konvensional khusus kelompok yang di nilai dengan teknik penilaian essay. Tidak adanya perbedaan pemahaman metakognisi biologi yang signifikan antara metode pembelajaran discovery dengan metode pembelajaran konvensional khusus kelompok yang di nilai dengan teknik penilaian multiple choice.

\section{DAFTAR PUSTAKA}

[1] Mulyati, T. (2016). Kemampuan Pemecahan Masalah Matematis Siswa Sekolah Dasar (Mathematical Problem Solving Ability of Elementary School Students). EDUHUMANIORA: Jurnal Pendidikan Dasar, 3(2), 1-20.

[2] Anonim. (2016, June 3). Pengertian Lingkungan Hidup, Unsur, Manfaat dan Upaya

Pelestariannya.1.https://lingkunganhidup.co/p engertian-lingkungan-hidup/.

[3] Soerjani, M. (1983). Ekologi Manusia dan Alam Semesta. Manusia Dalam Keserasian Lingkungan, 1-31.

[4] Irhami, S. N. (2019). Implementasi Pendekatan Kontekstual untuk Meningkatkan Gairah Siswa dalam Pembelajaran Biologi di Madrasah Aliyah Negeri 02 Banyumas. Jurnal Kependidikan, 7(1), 3-42. https://doi.org/10.24090/jk.v7i1.2827.

[5] Anonim. (2007). Materi Pelajaran Blogspot.com. Materi Pelajaran. http://materipelajaran.blogspot.com/2007/11/hakekatbiologi-sebagai-ilmu.html.

[6] Sulianto, J. (2008). Pendekatan Kontekstual Dalam Pembelajaran Matematika Untuk Meningkatkan Berpikir Kritis Pada Siswa Sekolah Dasar. Pendekatan Kontekstual Dalam Pembelajaran Matematika Untuk Meningkatkan Berpikir Kritis Pada Siswa Sekolah Dasar, 4(2), 14-25. https://doi.org/10.21831/pg.v4i2.555.

[7] Taufik, M., Sukmadinata, N. S., Abdulhak, I., \& Tumbelaka, B. Y. (2010). Desain Model Pembelajaran Untuk Meningkatkan Kemampuan Pemecahan Masalah Dalam Pembelajaran Ipa (Fisika) Sekolah Menengah Pertama Di Kota Bandung. Berkala Fisika, 13(2), 31-44.
[8] Putu Nyeneng, I. D., K, E., \& Abdurrahman, A. (2013). Analisis Hasil Belajar Fisika Siswa Berdasarkan Kemampuan Berpikir Konkret Dan Formal Sma. Jurnal Pembelajaran Fisika Universitas Lampung, 1(1), 120437.

[9] Erman, E. (2012). Latihan Menganalisis Kasus Olahraga Untuk Meningkatkan Penguasaan Konsep Biokimia Mahasiswa Ilmu Keolahragaan. Jurnal Pendidikan Dan Pembelajaran (JPP), 19(1), 94-101.

[10] Ihsan, M. S., Ramdani, A., Hadisaputra, S., \& Al Idrus, A. (2020). Pengembangan Instrumen Pemahaman Konsep Berbasis Komputer pada Pembelajaran Kimia. Jurnal Inovasi Pendidikan dan Sains, 1(1), 26-29.

[11] Andrian, D. (2015). Bervariasi dan Kreatif Dalam Mengajar. Kompasiana. https://www.kompasiana.com/dedeandrian/55 29357df17e61f14a8b45c4/bervariasi-dankreatif-dalam-mengajar.

[12] Indarini, E., Sadono, T., \& Onate, M. E. (2013). Pengetahuan Metakognitif Untuk Pendidik Dan Peserta Didik. Satya Widya, 29(1), $\quad 40$. https://doi.org/10.24246/j.sw.2013.v29.i1.p40 -46 ,

[13] Gozali, A. (2011). Experiment Research. Blogger.http://islamiceducation001.blogspot.c om/2019/02/experiment-research.html.

[14] Siswanto. (2006). Penggunaan Tes Essay Dalam Evaluasi Pembelajaran. Jurnal Kependidikan, 5 No.1, 55-61.

[15] Tumurun, S. W., Gusrayani, D., \& Jayadinata, A. K. (2016). Pengaruh Model Pembelajaran Discovery Learning Terhadap Keterampilan Berpikir Kreatif Siswa Pada Materi Sifat-Sifat Cahaya. Pengaruh Model Pembelajaran Discovery Learning Terhadap Keterampilan Berpikir Kreatif Siswa Pada Materi Sifat-Sifat Cahaya, 1(1), 101-110. https://doi.org/10.23819/pi.vli1.2936.

[16] Uki, Supardi. (2013). Aplikasi Statistika Dalam Penelitian (Adikita (ed.); 2nd ed., pp. 129-145). change publication.

[17] Zaenal, T., \& Cleopatra, M. (2015). Suplemen Aplikasi Komputer Dalam Penyusunan Karya Ilmiah (1st ed., p. 36). PT Pustaka Mandiri. 